\title{
The German
}

\section{Kommanditgesellschaft auf Aktien (limited partnership with shares)}

\author{
by Frank Wooldridge
}

\section{HISTORICAL BACKGROUND}

Although the German limited partnership with shares is no longer of much economic significance, it has an interesting history and is subject to a rather complex legal regime. There are apparently about 100-200 such limited partnerships in Germany at present. A similar entity was used in France during the eighteenth century to circumvent the requirement then imposed under French law of government consent for the formation of a company, and it is now possible to limit the liability of all the members of a rather similar one, the Société en commandite à responsabilité limitée which now exists in that country. Limited partnerships with shares came to be used in Germany in the nineteenth century, before they became regulated by the Allgemeines Deutsches Handelgesetzbuch (General German Commercial Code) of 1861. The Kommanditgesellschaft auf Aktien ( $K G a A$ ) became recognised as a kind of public company in an early version of the German Commercial Code, and it was treated as having legal personality in accordance with the German Aktiengesetze (statutes governing public companies) of 1937 and that of 1965, where it is dealt with in Book 2 of the statute.

The $K G a A$ has been defined in paragraph 178(1) $A k t G$ as a company which constitutes a separate legal entity, and in which at least one partner has unlimited liability to its creditors, and which also has shareholders who are not personally liable for the obligations of the company (Kommanditaktionäre), but who participate in the share capital. Until recently it was a matter of controversy whether other companies such as the private limited liability company or private limited liability company

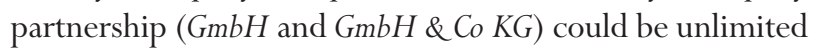
partners in a KGaA. This was held to be possible in a decision of the Supreme Court of 1997 (BGHZ 134, 392) even where there was no other unlimited partner.

Furthermore, the Handelrechtsreformgesetz of 1998 provided that the unlimited partner could be a private company limited partnership ( $\mathrm{GmbH}$ \& $\mathrm{Co}_{\mathrm{K}} \mathrm{K}$ ). The result of the above decision and legislation has been to significantly increase the number of $K G a A$, which at one time appear to have fallen to as little as 20. The decline in the use of this entity may have resulted from the complexity of the relevant legal regime and from the personal liability of the limited partner(s), which were found unattractive by persons desiring to form a business or engage in some other activity. The use of entities such as the $G m b H$ \& $C_{o} K G$, in which the $G m b H$ \& Co $K G$ is a personally liable partner and perhaps the only such partner, helps to escape from the disadvantages of unlimited liability; the $G m b H$ \& $C_{0} K G$ is itself an entity which does not involve such liability. It is a limited partnership, in which the "unlimited" partner is a $\mathrm{GmbH}$ which has limited liability.

\section{THE ROLE OF THE TWO TYPES OF MEMBER OF A KGaA}

The personally liable members or Komplementäre in a $K G a A$ have a role similar to that of the Komplementäre in a limited partnership (Kommanditsgesellschaft). The founders of the $K G a A$ may avoid personal liability by making use of the $G m b H$ \& $C_{0} K G a A$ mentioned in a previous paragraph. If they fail to do so, the unlimited partner will incur unlimited iability in accordance with paragraphs 161(2) and 128(2) of the Commercial Code. The Komplementäre are responsible for the management of the $K G a A$ and its representation. Paragraph 283 of the German Aktiengesetz sets out a number of matters in respect of which the rules contained in that law governing the management board (board of directors) of the public company shall apply by way of analogy to the general partners (personally liable partners) in a KGaA. The position of the Kommanditaktionäre (limited partner) in a KGaA is similar to that of shareholders in a public company. Paragraph 278(3) $A k t G$ thus provides that the provisions of Book 1 of the Aktiengesetz, paragraph 277 relating to the public company shall apply by way of analogy to the partnership 
limited by shares, unless the provisions which follow it (governing the KGaA or the absence of a management board) otherwise dictate.

\section{APPLICABLE RULES OF LAW}

According to paragraph 278(2) $A k t G$, the legal relationships of the general (unlimited) partners between themselves and with respect to the limited partners and third parties, and in particular the authority of the general partners to manage the business and to represent the company, shall be governed by the provisions of the Commercial Code relating to limited partnerships. The latter rules are contained in paragraphs 161-78 of the Commercial Code. Paragraph 278(3) AktG provides that the provisions of paragraphs 1-277 Akt G shall also apply by way of analogy to the $K G a A$, except where such application is excluded as a result of the rules contained in paragraphs 279-90 Akt $G$ or by reason of the absence of a management board.

The legal position of the limited partners is not regulated very clearly in the complex provisions of paragraph 278(2) and paragraph 278(3) $A k t G$. However, it follows from paragraph 278(2) $A k t G$ that the relationship between the body of limited partners (or shareholders) and the unlimited partners is governed by the provisions of the Commercial Code governing limited partnership. It appears that the administrative and property rights of individual unlimited partners are governed by Book 1 (paragraph 1-277) of the Aktiengesetz, but where the rights of such partners may only be exercised collectively they are governed by partnership law (See Kübler and Assmann, Gesellschaftsrecht, 6th ed, pub Müller, Heidelberg 2006, p255 in the present sense).

\section{THE FORMATION OF A KGaA}

Paragraphs 23 and 280-282 AktG govern the formation of a $K G a A$. The relevant rules are similar to those which concern the formation of an $A k t G$. The articles must be established by no less than five persons and take the form of a notarial deed. The latter must specify the par value of shares which have such a par value, and the number of shares in the case of an issue of no par value shares. The deed must also specify the usual price of the shares. There must be at least five founders on formation: however a $K G a A$ is deemed still to exist if the membership falls below five, even if there is only one member. It will be necessary to appoint members of the entity's supervisory and management boards as well as its auditors and to make the necessary contributions in cash or in kind to it in accordance with paragraphs 36a and 54(3) AktG.

The limited partnership with shares $(K G a A)$ comes into existence upon registration. According to paragraphs 214 and 191(2) UmwG (Umwandlungesetz) it is possible to transform a personalistic company into a KGAa. By paragraphs 226 and $245 \mathrm{Umw}_{\mathrm{w}}$, it is also possible to transform an AG or GmbH into a KGaA (see Kübler and Assmon, op cit p25).

\section{STRUCTURE AND ORGANISATION}

The structure of a $K G a A$ is somewhat different from that of a German public company. The partners who have unlimited liability are (unlike the management board of such a public company) not appointed by the supervisory board of the $K G a A$, but in accordance with its articles, which will require amendment when a new member of the management board is to be appointed or dismissed. The articles of the limited partnership with shares must contain particulars of each unlimited or general partner (paras 23(3) and (4) $A k t G$ and 281(1) $A k t G)$.

As the supervisory board does not appoint the unlimited partners who are responsible for the management of the company, its powers are reduced to those of an organ which carries out the resolutions of the limited partners unless the articles otherwise provide, and which represents those partners in litigation (paras 287(1) and (2) $A k t G$ ). The unlimited partners may not be members of the supervisory board (para 287(3) $A k t G$ ). The reduced role of the supervisory board also means that codetermination is of less significance in the $K G a A$ which may be an incentive to some entrepreneurs to make use of that entity.

If the articles so provide, it is possible for the partners who have unlimited liability to participate in the deliberations of the general meeting if they also hold shares which involve limited liability. According to paragraph 285(2) $A k t G$, the resolutions of the shareholders' meeting shall require the consent of the general partners insofar as they relate to matters which, in the case of a limited partnership, require the agreement of such general partners and the limited partners. Such consent may be required by statute as is the case with the approval of the annual financial statements (para 286(1) $A k t G$ ). Paragraph 285(2) $A k t G$ also provides that the consent of the general partners shall not be required for the exercise of the authority of the shareholders' meeting or of a minority of limited shareholders to appoint auditors or assert claims of the $K G a A$ arising from its formation or management.

By paragraph $284 A k t G$, a general partner may not, without the express consent of the other general partners and the supervisory board, enter into transactions on his or her own behalf or on behalf of another person in the company's fields of business. The general partners are jointly and severally liable to creditors for partnership obligations, in accordance with paragraphs 128 and 161(2) of the Commercial Code. Any agreement to the contrary has no effect. Limitation periods for claims against general partners are set out in paragraphs 159 and 160 of the Commercial Code, and are made applicable to the $K G a A$ by paragraph 161(2). The limited partners are not made liable for obligations incurred by the partnership. However, paragraph 164 of the Code indicates that although the 
limited partners are excluded from the management of the $K G a A$, they may object to an action by the general partners if it is outside the scope of ordinary business.

The general partners are bound by a duty of good faith towards one another and towards the limited ones. The limited partners also owe a duty of good faith towards each other, but this duty appears of less significance than the corresponding duty owed by the general partners to one another. As already indicated, juristic persons may be general partners in a $K G a A$. Such persons would seem to include any personalistic company, such as a $\mathrm{GmbH}$ (private limited liability company) or a $\mathrm{GmbH} \&$ Co $K G$ (private company limited partnership). Such an entity may be the only general partner, or there may be other such general partners.

A $K G a A$ has three organs - the general partners, the general meeting and the supervisory board. The general partners are responsible for the management and representation of the $K G a A$; each one of them has these powers, as follows, from paragraph 278(2) $A k t G$, together with paragraphs 161(2), 113(1) and 125(1) of the Commercial Code. It is noteworthy that paragraph 283 $A k t G$ stipulates that the provisions governing the management board of an $A G$ (Aktiengesellschaft) with regard to 14 different matters shall apply by way of analogy to the general partners. It is possible for the partnership agreement of a $K G a A$ to stipulate that the limited partnership with shares shall be represented by more than one unlimited partner, or that a particular individual shall be excluded from such representation. Such exclusion may also indicate exclusion from the management. The limited partners are required to give their consent to transactions which are not associated with the operation of the business of the KGaA by paragraph 116i(2) of the Commercial Code, but this requirement may be excluded or modified by the partnership agreement.

The partnership agreement may stipulate that the general or managing partners may only act jointly. If it does so, each business transaction requires the consent of all the general partners, unless there is a risk of delay. This provision, which is contained in paragraph 115(2) of the Commercial Code, may be modified by the partnership agreement.

The general meeting may be attended by all the limited partners (Kommanditaktionäre). If the general partners hold shares in the KGaA they may also attend such a meeting, but their voting rights will be restricted in accordance with paragraph 285(1) AktG. They will not be able to exercise voting rights on behalf of themselves or other persons in relation to resolutions governing certain prescribed matters. The limited partners have, on request, the right to be informed by the general partners on the affairs of the $K G a A$ at a general meeting in accordance with paragraph 131(1) AktG. The general meeting is also made responsible by paragraph 286(1) $A k t G$ for the establishment of the partnership's accounts.
Furthermore unless the partnership agreement provides otherwise, it follows from paragraph 278(2) Akt $G$ and paragraph 164 of the Commercial Code that it has to give its consent to extraordinary transactions. In addition, paragraph 285(2) $A k t G$ stipulates that resolutions of the general meeting shall require the consent of the general partners to the extent that they relate to matters which in the case of a limited partnership require the agreement of the general and the limited partners.

The supervisory board of a $K G a A$ may be regarded as a controlling and executive organ, which checks on the carrying out of transactions and the implementation of resolutions by the $K G a A$. It is evident that the supervisory board has a less significant role than that of an $A G$. It cannot issue subordinate legal rules for the conduct of business management by the board, unless it is permitted to do so by the partnership agreement (see Kübler and Assmann, op cit, p 258 in this sense).

It is unclear whether paragraph 111(4) $A k t G$, which provides that the partnership agreement or the supervisory board may determine that specific kinds of transactions may be entered into only with the consent of the supervisory board is applicable to the $K G a A$ as well as to the AG.

\section{PROVISIONS OF A FINANCIAL NATURE}

A $K G a A$ is not only financed by the contributions of the limited partners or shareholders, but also by contributions made by the unlimited or general partners: the latter are not specifically required to make contributions, but may do so (paragraph 281(2) $A k t G$ ). The capital provided by the limited partners (Grundkapital) must amount to at least $€ 10,000$ (paras 278(3) and $7 A k t G$ ). Their shares may be issued as par value shares or no par value shares. Contributions made by the general partners are not governed by the rules contained in the Aktiengesetz concerning the provision and maintenance of capital. Furthermore, the rules contained in paragraph 27(2) AktG concerning contributions in kind are inapplicable to the general partners: thus their contributions may consist of the obligation to provide services. The distribution of profits and losses between the general and limited partners is governed by paragraph 121 of the Commercial Code, unless the partnership agreement provides otherwise, which is usually the case (see Kübler and Assmann, opcit, 6th edition, p 259 in this sense). Paragraph 121 places emphasis on the partners' share in the capital.

A $K G a A$ may issue bonds or grant options to purchase its shares, or have recourse to loans from its limited partners. If the latter persons are in a position to exercise influence on the business of the $K G a A$, and thus to have responsibility for financing, they may incur liability in the event of the repayment of a loan made by them which has to be regarded as a substitute for capital. A KGaA may also obtain loans from its unlimited partners, who may become liable 
in the same way. Such liability will be unlimited if the relevant partner is a natural person, but such liability may be limited if the "unlimited" partner is an artificial person such as a $\mathrm{GmbH}$.

\section{CODETERMINATION}

The $K G a A$ is subject to the rules contained in the Codetermination Act of 1976, and those in the One-Third Participation Act (Drittelbeteiligungsgesetz) of 2004. It is not subject to the Codetermination Acts governing the coal, iron and steel industries because the legislature took account of the fact that there were no $K G a A$ in these industries. The Act of 1976 applies to KGaA which regularly employ more than 2,000 persons, and requires one half of the members of the Aufsichtsräten of such entities to consist of representatives of the employees. The Act of 2004 applies to $K G o A$ which employ at lest 500 persons, and requires one-third of the supervisory boards of such entities to consist of representatives of the employees. The powers of the supervisory board are somewhat limited, and it is not empowered to appoint the members of the board of management of a $K G a A$.

Dr Frank Wooldridge

\section{Clarification from author's previous article}

In the author's article "Duty of care and responsibilities of the management board of a German public company," published in the Summer 2010 issue of Amicus Curiae, the author referred (at p 31) to section 172 of the Companies Act 2006. He would like to make it clear that the provisions of section 172 do not involve a pluralistic approach as they treat the members' interests as paramount (see Gower and Davies, Principles of Modern Company Law, 8th ed, Sweet \& Maxwell, pp 508-10). 